\title{
5 \\ Coinage as 'Code' in Ptolemaic Egypt
}

\author{
J. G. Manning
}

\section{INTRODUCTION}

In this chapter I discuss the use of money in Ptolemaic Egypt in relationship to the development of the state. My aim here is to summarize some recent work and to set the process of monetization into a broader context of state development. The topic of money and coinage in the ancient world is enormously complex and work is ongoing on several fronts. ${ }^{1}$ Much of what Moses Finley believed about money has been disputed in recent years. ${ }^{2}$ The most important scholarly shifts have resulted from work on banks and banking, and the closer examination of regions and historical periods ignored by Finley, Ptolemaic Egypt being an important case in point. The last decade has witnessed an explosion in both technical studies of coinage and more general economic treatments. ${ }^{3}$ Despite this, however,

I thank William Harris, Sitta von Reden, and Andrew Monson for valuable comments on earlier drafts.

1 The forthcoming work on Ptolemaic money by Sitta von Reden will be important, and will treat far more thoroughly than I can the issues that I can only touch on here. I shall not treat the physical description of Ptolemaic coinage since von Reden has dealt with this excellently. I am grateful to her for showing me a draft of the book and for allowing me to signal its appearance. Some of the issues were briefly addressed by von Reden in 'Money and Coinage in Ptolemaic Egypt. Some Preliminary Remarks', in Akten des 21. Internationalen Papyrologenkongresses: Berlin, 13.-19.8.1995 (Stuttgart, 1997), 1003-8.

2 Trends in scholarship are well summarized in S. von Reden, 'Money in the Ancient Economy: A Survey of Recent Research', Klio 84 (2002), 141-74.

3 Good surveys by A. Bresson, 'Coinage and Money Supply in the Hellenistic Age', in Z. H. Archibald, J. K. Davies, and V. Gabrielsen (eds.), Making, Moving and 
the issues involved in the study of Ptolemaic monetary history are complex, and the data scattered over technical publications in Greek and demotic Egyptian papyrology, and numismatics as well as in archaeological site reports. The economic historian of the period is always at risk in over- or underemphasizing one particular data-set or point of view. While some scholars have emphasized the cultural or political context of coinage, others have concentrated on the use of coinage in private transactions or its role in economic growth. In this chapter I set the monetization of the economy into the larger process of asserting sovereignty over Egyptian institutions that is also reflected in the encapsulation of Egyptian law and Egyptian temples within the new state structure. All of the available evidence points to Ptolemy II Philadelphus as the key driver in the process, in part a reflection of the lag between the takeover by Alexander and the political processes of gaining control of the country, a country which went from a largely unmonetized (i.e. coin usage) economy to a largely monetized one during the course of the third century BC.

Coinage, of course, was of fundamental importance to the finance of Hellenistic states, but an examination of the process of monetizing the taxation mechanisms in Egypt illustrates one of the best reasons why the Ptolemies were so successful. By the end of the third century $\mathrm{BC}$, for example, there was an independent bronze coinage, a fact that coincides well with the stronger Ptolemaic institutional control throughout Egypt. ${ }^{4}$ I draw a distinction between cash transactions within the fiscal system (monetary accounting, tax payments) and private cash transactions, which were largely undocumented and are therefore more difficult to study in absolute terms, although it is clear that the Ptolemaic insistence on coinage in taxation and the use of coinage as a unit of account had profound effects, as Sitta von Reden argues (forthcoming, further below).

The use of coinage is one of the key features of Hellenistic economies, and, because of its rich documentation, Ptolemaic Egypt

Managing: The New World of Ancient Economies, 323-31 BC (Oxford, 2005), 44-72; F. de Callataÿ, 'A Quantitative Survey of Hellenistic Coinages: Recent Achievements', in Archibald et al. (eds.), 73-91.

4 J. G. Manning, Land and Power in Ptolemaic Egypt. The Structure of Land Tenure (Cambridge, 2003), 161-4. 
holds a special place in monetary history, although it has not been treated as such by economic historians. Primarily thanks to the documentary papyri, and increasingly the tax receipt ostraca, Ptolemaic Egypt offers us the best ancient material to study the impact of Greek economic institutions on a new region. Even before the Ptolemies, Egypt offers important material evidence for the history of monetization. Like so much else in Hellenistic economic structure and organization, strong institutional continuities existed with both Persian imperial practice and the fourthcentury Greek experience, both connected by the theoretical concerns of Xenophon, Aristotle, and his students. The well-known text of Ps.-Aristotle, Oikonomika, Book 2, for example, most of it composed, probably, at the end of the fourth century BC, reveals much about the mentalité and the taxation policy of Hellenistic states, whether the Seleucid kingdom is the specific subject of the treatise or not. ${ }^{5}$

It has generally been assumed that the use of coinage had profound effects, but it is important to bear in mind that Egypt had been partially monetized for quite some time before the Ptolemies, being a crucial point of contact between the Greek world and the Persian Empire. It was certainly, therefore, well connected to the eastern Mediterranean economy before Alexander. The joining of the Greek 'stock of knowledge' to the ancient Egyptian agrarian economy and its social structure centred around the basin irrigation system is what makes the study of money in the Ptolemaic period, despite its many remaining technical problems, particularly with the bronze coinage, so interesting. Money in the form of coinage existed in Egypt since at least the seventh century вс. ${ }^{6}$ This is important in understanding the mentalite of Egyptians in the new world that was the Ptolemaic economy. What was new was the process of monetization, the increased demand for coin through taxation and, probably, the increased use of coin in private transactions. ${ }^{7}$ But there is an important caveat. The documentary

5 See the very good discussion by G. G. Aperghis, The Seleukid Royal Economy. The Finances and Financial Administration of the Seleukid Empire (Cambridge, 2004), 117-35. On the date, ibid. 129-35.

6 For coins minted in Egypt dating to the Persian king Artaxerxes III (probably at Memphis), although found elsewhere, see S. P. Vleeming, 'Coins of Pharaoh Artaxerxes III', in Some Coins of Artaxerxes and Other Short Texts in the Demotic Script Found on Various Objects and Gathered from Many Publications (Leuven, 2001), 1-4.

7 For a good treatment of similar issues later, see W. C. Schultz, 'The Monetary History of Egypt, 642-1517,' in C. F. Petry (ed.), The Cambridge History of Egypt (Cambridge 1998), i. 318-38. 
evidence is far from clear enough to be certain that there was extensive use of coinage in small transactions, and it is likely that there existed in Egypt as elsewhere in the Hellenistic world a gap between urban areas that were more monetized and rural areas that remained 'zones of low monetization'. ${ }^{8}$

\section{HISTORY OF 'MONEY' IN EGYPT}

Metals and grain were used as media of exchange, a store of value, and a means of payment for more than a millennium before coins. Gold rings and copper blades as well as grain were well known in New Kingdom transactions, and a nominal exchange rate between copper and silver was fixed at 1:60.9 An important Ramesside period letter shows, for example, that the harvest tax collected on private land was paid in 'gold into the treasury of Pharaoh'. ${ }^{10}$ The term 'gold' in this text is susceptible to several interpretations but it is at least plausible that the term refers in a general sense to 'money' and that taxes in grain were conceived of in monetary terms. A silver standard was in place by the end of the New Kingdom. Under the Persians, the treasury of Ptah in Memphis was the guarantor of a silver bullion standard, and this standard may have been more widely accepted than in earlier times. ${ }^{11}$

8 Bresson, 'Coinage and Money Supply' [n. 3], 66.

9 Good summaries of the pharaonic Egyptian economy (i.e. primarily the New Kingdom economy, when the documentary evidence is at its thickest) may be found in B. J. Kemp, 'The Birth of Economic Man', in Ancient Egypt. Anatomy of a Civilization (London, 1989), 232-60; B. Menu, 'Le système économique de l'Égypte ancienne', Méditerranées 17 (1998), 71-97. Barter exchange measured against fixed value of a commodity (silver, copper/bronze, grain) is well known in ancient Egypt and described by J. J. Janssen, 'Prolegomena to the Study of Egypt's Economic History during the New Kingdom', Studien zur altägyptischen Kultur 3 (1975), 127-85, and by B. J. Kemp (see above). On the dangers of assuming that any pre-modern state had the ability to guarantee exchange rates, see the cautionary remarks of Schultz, 'Monetary History' [n. 7], 322-3.

10 P. Valençay 1; A. B. Gardiner, 'A Protest against Unjustified Tax-demands', Revue d'Égyptologie 6 (1951), 115-33; S. L. D. Katary, Land Tenure in the Ramesside Period (London, 1989), 207-16; D. A. Warburton, State and Economy in Ancient Egypt. Fiscal Vocabulary of the New Kingdom, Orbis Biblicus et Orientalis 151 (Fribourg, 1997), 136-7.

11 On money in pre-Ptolemaic Egypt, see F. Daumas, 'Le Problème de la monnaie dans l'Égypte antique avant Alexandre', Mélanges de l'École française de Rome 89 
In the so-called Third Intermediate Period (1069-664 вC), some taxes were clearly monetized. A 10 per cent transfer tax is known in a few documents. ${ }^{12}$ Increased monetization seems to be associated with a higher volume of trade with Greece beginning in the seventh century BC, at the same time as the Greek trading colony at Naukratis in the western Delta was established. ${ }^{13}$ It is therefore not surprising to see an increase in coin hoards in the sixth century BC. If Kim's suggestion is correct, the use of small change in the Greek world speaks to a deeply embedded institution across the range of the social hierarchy and, as a Greek institution, would have been familiar to Greek immigrants in Egypt. ${ }^{14}$ As Muhs rightly argues though, monetized transactions were still limited to a small elite circle, preponderantly soldiers, and coinage was used mainly as bullion. ${ }^{15}$ By the fourth century $\mathrm{BC}$, the evidence for the use of bronze coins in small transactions increases. Persian imperial practice of demanding some taxes in silver must have had an effect in monetizing private transactions, although the extent of it can hardly be estimated.

Papyrus Hou 12, a money loan, perhaps for the purpose of purchasing of a cow, is one example of a Persian period loan of money written in demotic Egyptian. ${ }^{16}$

Year 35, 2d month of the shemu season (Payni) under Pharaoh [Darius]. Says the [Goose]herd [of the Domain of Amon, Petash] otmef, son of Inarou, his mother Te[te] tichy, to the Gooseherd of the Domain of Amon (2) [ .........., son of In] arou, his mother Obastorer: [I have received from you] 3 [kite silver]

(1977), 425-42. See e.g. the demotic marriage contract dated to the reign of Darius I from Saqqara published by C. J. Martin, 'A Twenty-Seventh Dynasty "Marriage Contract” from Saqqara', in Studies in Honour of H. S. Smith (London, 1999), 193-9; S. P. Vleeming, The Gooseherds of Hou (Pap. Hou). A Dossier Relating to Various Agricultural Affairs from Provincial Egypt of the Early Fifth Century BC (Leuven, 1991), 89.

12 On the history of the transfer tax, see M. Depauw, The Archive of Teos and Thabis from Early Ptolemaic Thebes. P. Brux. Dem. Inv. E. 8252-8256 (Turnhout, 2000), 58-63; and briefly, B. Muhs, Tax Receipts, Taxpayers, and Taxes in Early Ptolemaic Thebes: Demotic and Greek Ostraca in the Oriental Institute Collection, Oriental Institute Publications 126 (Chicago, 2005), 3-4.

13 Muhs, Tax Receipts [n. 12], 4.

14 H. S. Kim, 'Small Change and the Moneyed Economy', in P. Cartledge, E. E. Cohen, and L. Foxhall (eds.), Money, Labour and Land. Approaches to the Economies of Ancient Greece (London, 2002), 44-51.

15 Muhs, Tax Receipts [n. 12], 4.

16 Suggested by Vleeming, Gooseherds of Hou [n. 11], 161. 
of the treasury of Ptah, [refined, which you gave] me; it is I who will give you 6 kite silver of the treasury of Ptah, refined, ${ }^{17}$ (3) [because of] them, in year 36, $1^{\text {st }}$ month of the peret season (Tybi). If I fail [to give] you [these] 6 kite silver of the treasury [of Ptah, refined], in year $36,1^{\text {st }}$ month of the peret season (Tybi) they will bear (interest) against me, $1 / 10^{\text {th }}$ of silver to (4) each (kite of silver), from year 36, 2d month of the peret season (Mecheir) onwards, while they don't stop as interest [in any month (and) any year] that they will be with me, while interest (will) bear as interest against me (5) again, and also this interest which is (mentioned) above, till whatever ever [sic] they would reach; and I will give then [to you and also their interests]. This(?) money which is (mentioned) above and also their interests [will] befall on me (6) (and) on my children, and also (on) the pledges that you will want [from me, all, all, (as) houses, slave, (female) slave, cow, d donkey, and cattle, barley, emmer, (7) silver, bronze, clothing, everything as chattels, and you will take them [to you] because of them, till [you have filled them with the above money and their interests]. [I shall not be able to say], 'I have given to you money (or) interest among them, while (8) this document is in your hand. In writing of Onnōfri, son of Tethotefōnch.

Four witnesses sign on the verso of the contract. ${ }^{18}$

There are only a handful of pre-Ptolemaic money loan contracts, and caution must be exercised in drawing conclusions about the extent of private lending of money. ${ }^{19}$ While we have no comparable evidence from Egypt of monetary theory to rival Xenophon or Aristotle, it seems difficult to believe that the trends in Greek thought in the fourth century would not have at least been observed in the fourth-century economy of Egypt. The imitation owl coins minted in Egypt in this period may reflect a link between Greek theory and Egyptian practice before the Ptolemies, and the enormous quantity of precious metal from the Persian treasury circulated as coin as the result of Alexander's campaigns must surely have affected early Ptolemaic Egypt. ${ }^{20}$

\footnotetext{
17 Here the term 'refined' refers to weight standards (not the fineness of silver content) of the temple of Ptah in Memphis against which silver 'pieces' were weighed.

18 Translation of Vleeming, Gooseherds of Hou, whose textual notes are invaluable.

19 See briefly Depauw, Archive of Teos [n. 12], 146-7.

20 F. de Callataÿ, 'Les Trésors achéménides et les monnayages d'Alexandre: espèces immobilisées et espèces circulantes', Revue des Études Anciennes 91 (1989), 259-74.
} 


\section{THE PTOLEMAIC ECONOMY}

The rather famous and oft-quoted passage in Saint Jerome's Commentary on the Book of Daniel (XI. 5) stating that the annual revenue of Ptolemy II amounted to 14,800 talents of silver and 1.5 million artabae of wheat, whether we believe the figures or not, tells us a good deal about the scale of the Ptolemaic royal economy and the sources of revenue: direct taxation of agricultural production, some of which, fodder crops for example, were converted into coin, and the taxation in cash of persons and private transactions. ${ }^{21}$ The agricultural sector was of course dominant, but if Jerome's figures are to be considered meaningful in any way, the amount of cash in the annual revenue is the more impressive figure. There were, obviously, good reasons to keep revenue in grain. Neither wheat nor silver was new with Ptolemy I, but Greek fiscal institutions probably allowed for a greater (and more efficient?) capture of revenue than at any time in previous Egyptian history. It was under the Ptolemies that Greek fiscal institutions, coinage, banks, and tax farming, were first introduced in Egypt. The subsequent monetization of the traditional agricultural economy marks a turning point, somewhat earlier than usually posited, in the rise of the 'mercantile state. ${ }^{22}$ It is now, I believe, communis opinio that the Ptolemaic transition in the early third century BC was marked more by continuity with Persian rule than discontinuity. The fact that Ptolemy acted at first as a satrap is only the most obvious and public signal that Ptolemaic rule in Egypt maintained well-established and functioning institutions. Like the Seleucid dynasty, the Ptolemies established themselves on a Persian foundation and provided a new incentive structure for state service and private economic activity. ${ }^{23}$ Egypt had been an important trade axis connecting the Mediterranean to the east and south for a millennium before the Ptolemies, but Greek immigration, the new cities of Alexandria and Ptolemais, and Greek fiscal institutions had profound effects. The intellectual foundations for the use of coinage

21 See further Manning, Land and Power [n. 4], 135 n. 21, on the figures.

22 J. Hicks, A Theory of Economic History (Oxford, 1969).

23 A good survey of Persian history: P. Briant, From Cyrus to Alexander. A History of the Persian Empire (Winona Lake, Ind., 2002). 
in state finance expressed in Ps.-Aristotle, Oikonomika 2. 1-2, is as important for understanding Ptolemaic policy as it is for Seleucid. It is in this setting that coinage and the increase in monetization should be understood.

The economic policy of the early Ptolemaic kings, and I think 'policy' is a fair term to use, was (to judge mainly from a reading of P. Rev.) predictability, stability, insulation from risk (at least in theory), and, above all else, revenue capture by, in theory, taxing anything that moved, including animals. ${ }^{24}$ Change came in economic intensification-increased urbanization, increased long-distance trade, and increased monetization, especially in the realm of taxation, and in structure-intensified agrarian production, royal banks, and royal granaries. Along with this change came rural unrest that, on one occasion (207-186 BC), led to the secession of most of the Thebaid from the Ptolemaic state, and consequently a loss of tax revenue. ${ }^{25}$ The increased presence of Greeks and their role in the bureaucratic hierarchy, in military service and in other economic activity, altered the structure of social power in terms of language (the increased use of Greek in the villages) and access to rents (i.e. income). Above everything else, however, stands the Ptolemaic closed currency system that on the one hand set off Egypt and the Ptolemaic imperial possessions from other Hellenistic states, and on the other became established as a universal fiscal institution within Egypt.

Some considerable advances in the understanding of Ptolemaic coinage have been made recently. ${ }^{26}$ It is clear that Ptolemaic taxation

24 For P. Rev., see B. P. Grenfell and J. P. Mahaffy, The Revenue Laws of Ptolemy Philadelphus (Oxford, 1896), C. Préaux, L’Économie royale des Lagides (Brussels, 1939), 65-93, J. Bingen, Papyrus Revenue Laws, Sammelbuch griechischer Urkunden aus Ägypten, suppl. 1 (Göttingen, 1952), Bingen, Le Papyrus Revenue-Laws. Tradition grecque et adaptation hellénistique (Opladen, 1978). On Ptolemaic intentions, see A. E. Samuel, From Athens to Alexandria: Hellenism and Social Goals in Ptolemaic Egypt, Studia Hellenistica 26 (Leuven, 1983).

25 On the revolts of the period, see the summaries in B. C. McGing, 'Revolt Egyptian Style. Internal Opposition to Ptolemaic Rule', Archiv für Papyrusforschung 43 (1997), 273-314, Manning Land and Power [n. 4], 164-71, and the study by A.-E. Véïse, Les 'Révoltes égyptiennes.' Recherches sur les troubles intérieurs en Égypte du règne de Ptolémée III à la conquête romaine, Studia Hellenistica 41 (Leuven, 2004). The causes of the revolts are unclear.

26 For a good summary see R. A. Hazzard, Ptolemaic Coins. An Introduction for Collectors (Toronto, 1995). See also O. Picard, 'L'Apport des monnaies des fouilles 
policy that required some taxes to be collected, or at least calculated, in terms of money, and the creation of banks, played key roles in monetization. ${ }^{27}$ There may have been a regional difference in the process, influenced by where Greeks settled. On the basis of the scanty evidence, commodity prices appear to have remained relatively stable. ${ }^{28} \mathrm{New}$ fiscal measures were taken in the production, manufacture and sale of key items such as flax, salt, beer, and for certain oil crops. Here the Ptolemaic state utilized competitive bids and labour contracts that fixed workers in a specific place over the length of the contract, often supplied raw materials and tools, and granted state licences for the sale of the finished product (the socalled Ptolemaic 'monopolies', although they scarcely were). The aim here, as throughout the Ptolemaic fiscal system, was to secure labour, and to produce predictable income for the state. ${ }^{29}$

There was initially a tri-metallic coin system, although gold was hardly circulated. The silver and bronze coins were linked through a fixed exchange mechanism, adjusted at the end of the third century BC. The taxation policy of the Ptolemies that required some payments to be made in coin, and the control of 'monopoly' industries, accelerated the circulation of coin (bronze) throughout Egypt. The spread of banks from urban centres to (some) Egyptian villages was not only the crucial process in linking taxpayers to taxation collection but was also an important nexus between cash and kind in rural areas where the circulation of coinage may have been limited..$^{30}$

d'Alexandrie', Études alexandrines 10 (2004), 81-90; F. Burkhalter and O. Picard, 'Le Vocabulaire financier dans les papyrus et l'évolution des monnayages lagides en bronze', Études alexandrines 10 (2004), 53-80; S. von Reden, Money in Ptolemaic Egypt (Cambridge, forthcoming).

27 Cf. D. Rathbone, 'The Ancient Economy and Graeco-Roman Egypt', in L. Criscuolo and G. Geraci (eds.), Egitto e storia antica dall'ellenismo all'età araba. (Bologna, 1989), 159-76; von Reden, Money [n. 26].

28 Land prices: A. E. Samuel, 'The Money Economy and the Ptolemaic Peasantry', Bulletin of the American Society of Papyrologists 21 (1984), 187-206, H. Cadell, 'Le Prix de vente des terres dans l'Égypte ptolémaïque d'après les Papyrus grecs', in S. Allam (ed.), Grund und Boden in Altägypten (Tübingen, 1994), 289-305. Cf. K. Baer, 'The Low Price of Land in Ancient Egypt', Journal of the American Research Center in Egypt 1 (1962), 25-45.

29 E. G. Turner, 'Ptolemaic Egypt', in $C A H$ vii. 1, 2nd edn. (Cambridge, 1984), 151-53; von Reden, Money [n. 26]. P. Rev. is the key document.

30 Von Reden, 'Money in the Ancient Economy' [n. 2], 147; D. Foraboschi and A. Gara, 'L'economia dei crediti in natura (Egitto)', Athenaeum 70 (1982), 69-83. 
The paucity of price data preserved in the papyri is a serious barrier to understanding the long-term performance of the Ptolemaic economy. References to items in the papyri can be frustratingly obscure, small items such as hoes are rarely given values, we are not always sure whether a price is reckoned in silver or bronze, and there are significant gaps in our information (e.g. for the price of wheat from the mid-third century $\mathrm{BC}$ to $209 \mathrm{BC}) .{ }^{31}$ The data derived from penalty clauses in contracts can mislead. The explanation for the long-term history of commodity prices is exacerbated by our lack of knowledge about the amount of money in circulation and the velocity of circulation. ${ }^{32}$ The supposed price inflation that occurred in the reign of Ptolemy IV Philopator has received extensive comment and various explanations. ${ }^{33}$ Earlier analyses have focused on the reduction in precious metal of the silver coins, in a new bookkeeping system, or in a reduction of the weight of the bronze drachma and the consequent increase in the value of coin in circulation. ${ }^{34}$ Much of the so-called price inflation, however, is derived not from a single new bronze accounting standard but from multiple re-tariffings of the bronze coins against silver and gold. ${ }^{35}$ An independent bronze standard was introduced at the end of the third century вс.

The Egyptian rural economy was long used to monetized exchange (usually reckoned in grain against fixed values), and grain and wine continued to be used as such into the Roman period. ${ }^{36}$ While it is clear that the Ptolemies were increasingly interested in generated

31 Samuel, 'The Money Economy' [n. 28]. For the gap in wheat prices, see H. Cadell and G. Le Rider, Prix du blé et numéraire dans l'Égypte de 305 à 173, Papyrologica Bruxellensia 30 (Brussels, 1997).

32 R. S. Bagnall, review of Cadell and Le Rider [n. 31], Revue Suisse de Numismatique 78 (1999), 197-203.

33 T. Reekmans, 'The Ptolemaic Copper Inflation', Studia Hellenistica 7 (1951), 61-119; K. Maresch, Bronze und Silber. Papyrologische Beiträge zur Geschichte der Währung im ptolemäischen und römischen Ägypten bis zum 2. Jahrhundert n. Chr., Papyrologica Coloniensia 25 (Cologne, 1996); Cadell and Le Rider, Prix du blé [n. 31]; Bagnall, review [n. 32].

34 Reekmans, ibid.

35 Bagnall, review [n. 32], 198; von Reden, Money [n. 26].

36 Wine: W. Clarysse and K. Vandorpe, 'Viticulture and Wine Consumption in the Arsinoite Nome (P. Köln V 221)', Ancient Society 28 (1997), 67-73. On Egyptian mentalities, see J. Bingen, 'Économie grecque et société égyptienne au IIIe siècle', in H. Maehler and V. M. Strocka (eds.), Das Ptolemäische Ägypten. Akten des Internationalen Symposions 27.-29. September 1976 in Berlin (Mainz, 1978), 211-19. 
revenue in coin, the continued use of grain as a medium of taxation limited Ptolemaic ability to monetize the rural economy completely. ${ }^{37}$ But that, of course, was not the aim of the Ptolemaic fiscal system. Contract wage labour, in the agricultural sphere as well as for shortterm building projects, canal building and the like, was common, with daily or monthly payment being done in kind as well as cash. ${ }^{38}$ Like so much else with the Ptolemies, what is characteristic was the intensification of trends seen in the Saite and Persian periods (664-332 BC) increased urbanization, long-distance trade, and monetization. This last was significantly aided by the Greek institution of banking. ${ }^{39}$ We can add one more concept to the definition of 'monetization', and that is that valuations are given in terms of money (i.e. the Ptolemaic coinage system added a new element of numeracy to accounting methods), and wrongs are adjudicated in terms of money. Here the legacy of Rome that Hicks discussed ${ }^{40}$ should be understood as resting on a Ptolemaic foundation. The use of coinage, then, was part of a larger state project to establish new standards and increase stable revenue.

\section{COIN AS 'CODE' IN PTOLEMAIC EGYPT}

The use of coined money in the taxation system, as payment in wage labour and in small transactions was a new feature of the Egyptian economy under the Ptolemies, and it is Ptolemy II who appears as a major reformer. This king did two important things with respect to coinage: (1) Reform of the taxation system, most importantly in the institution of the capitation tax known as the salt $\operatorname{tax}^{41}$ and (2) institution of the tax farming system supported by a public auction for the sale of tax collection contracts. The salt tax was the major new

37 Samuel, 'The Money Economy' [n. 28], J. Rowlandson, 'Money Use among the Peasantry of Ptolemaic and Roman Egypt', in A. Meadows and K. Shipton (eds.), Money and its Uses in the Ancient Greek World (Oxford, 2001), 149.

38 Treated well by von Reden, Money [n. 26].

39 R. Bogaert, Trapezitica Aegyptiaca. Recueil de recherches sur la banque en Égypte gréco-romaine, Papyrologica Florentina 25 (Florence, 1994).

40 J. Hicks, A Theory of Economic History (Oxford, 1969), 70.

41 On this tax, see Muhs, Tax Receipts [n. 12], 41-51; W. Clarysse and D. Thompson, Counting the People in Hellenistic Egypt (Cambridge, 2006), ii. 36-89. 
institution in the process of monetizing the economy and a key source of state control; indeed it is the monetization of taxes, and the bureaucratic infrastructure that revolved around it, that stands out as the single most important aspect of the internal history of Egypt in the last three centuries BC. The payment of taxes in the Ptolemaic period was divided into two types: those collected (or at least calculated) in terms of grain, and those taxes that were demanded in coin. Certain taxes on agricultural production were also required to be paid in coin. The most important of these were the apomoira, a tax on vineyards, the tax on fruit trees, and a fodder tax. Surely by the second century BC, and probably before, Egyptian temples were fully involved in the cash game. Recently published texts from Edfu, for example, suggest that temples were involved in the marketing of wine. ${ }^{42}$ Other forms of business, beekeeping for example, were cash businesses in which the state normally received cash rents. ${ }^{43}$ But as both von Reden and Rowlandson have pointed out recently, the persistence of the Roman policy of collecting the tax on grain-bearing land in kind for pragmatic reasons formed a natural limitation to monetizing the economy in coin.

The 'Ptolemaicization' (i.e. political systemization or institutionalization) of Egypt, that is, the desire to impose a homogenous bureaucratic culture and the adoption of Ptolemaic state institutions by the population of Egypt, was not accomplished by coercion alone, although coercive force may have occasionally played a role in the enforcement of state rules, including tax collection. Ptolemaic development was also driven by the adaptation to pre-existing institutions. Development was, therefore, variable across time and region in Egypt in the third century вс, but was probably well established by the second century вс. The story of the shift to Ptolemaic institutions is a complicated one and involves social processes on many different levels, from institutional signals (the Greek language, circular letters, and other kinds of 'instruction' texts and so on ${ }^{44}$ ) by the central state, to incentive

42 P. Carlsb. 409 and 410. See now M. Schentuleit, The Carlsberg Papyri 9: Aus der Buchhaltung des Weinmagazins im Edfu-Tempel. Der demotische P. Carlsberg 409, CNI Publications 32 (Copenhagen, 2006).

43 See the comments by Bingen, 'Économie grecque' [n. 37].

44 For a well-known example of 'instruction', see P. Tebt. 703, with the comments of D. J. Crawford, 'The Good Official of Ptolemaic Egypt', in Maehler and Strocka (eds.), Das Ptolemäische Ägypten [n. 36], 195-202. 
structures and individual choice by settlers and local populations throughout Egypt. Greeks, of course, were in an advantaged position in certain respects initially in their use of the Greek language and their familiarity with coined money. ${ }^{45}$ The Zenon archive in this context, documenting newly exploited land, and a high degree of monetization, is exceptional.

Coinage, to be sure, represented the authority of the king, and the control of minting from a central point in Alexandria highlights this fact, as of course does the iconography of the coins themselves. That authority is found not only in the demand for taxes and the fixing of the value of coins but also in the power of the king to assign tenure to land, to survey fields, to establish nome boundaries, to conduct censuses of men and animals, to guarantee justice, to establish weights and standards, and so on. ${ }^{46}$ Coinage, then, was a new institution brought to bear in the ancient power struggle between central and local authority in Egypt, and the establishment of the Ptolemaic mint in Alexandria by 320 вс was an important signal by the new sovereign state, a point also well stressed by von Reden (forthcoming).

Demotic legal texts show us the history of the relationship between money and the state in the first millennium вс rather clearly. In Saite demotic documents, as well as Aramaic ones, amounts of money are mentioned in terms of weighed pieces of silver against a certain weight standard of a temple: 'silver, $\mathrm{x}$ deben of the Treasury of Ptah, refined'. The Egyptian weight standard was known as the deben, and it was at the treasury of the most important temple of the SaitePersian and Ptolemaic period, that of the god Ptah at Memphis, where the standard measures were fixed. This important role of the temple was replaced in the Ptolemaic period when the phrase 'silver, $\mathrm{x}$ deben of the Treasury of Ptah, refined' was an archaism with the new meaning not of a standardized weight but of a specific amount of silver in Ptolemaic coins. ${ }^{47}$ This was a subtle yet important shift in

45 See J. Bingen, 'Les Tensions structurelles de la société ptolémäique', in Atti del XVII Congresso internazionale di papirologia (Naples, 1984), 921-37, on this point.

46 Hicks, A Theory [n. 40], 63-80. The institution of public auction was a new mechanism introduced by the Ptolemies to assign tenure to land, among other things including the right to collect taxes.

47 See Vleeming, Gooseherds of Hou [n. 11], 88-9, with literature. 
political and economic power away from Egyptian temples and into the hands of the Ptolemaic kings.

The fixing of the value of each coin and the determination of how many of each type of coin should circulate was an additional source of sovereign power of the kings (Ps.-Arist., Oik. 2. 1. 3).48 Thus, coins, their circulation, and use are strongly linked to the early Ptolemaic project to integrate the royal economy with the ancient institutional structure of Egypt. Von Reden (forthcoming) rightly stresses the connection between coinage and royal legitimacy. A taxation system that demanded payments in coin was an imposition of state authority on villages just as, in ancient times, the king imposed a rural order in the establishment of nome (i.e. district) boundaries. The act of demanding coin was an act of sovereignty, a constraint on the hinterland, and a means by which state authority was imposed, at least in theory, in a uniform or standardized way. It should be stressed here that while the Ptolemaic kings attempted to impose a political order on Egypt, this order was neither uniform nor completely accepted. The establishment of coinage as a means of the payment of taxes and in small transactions was part of the imposition of a larger political order, related, for example, to the formation of a new legal order that incorporated both Greek and Egyptian legal traditions into one state system. The process in Ptolemaic Egypt is rather different than that described by Seaford for the Greek polis, ${ }^{49}$ and it did not involve as much of a threat against the local elite that undermined traditional society. ${ }^{50}$ In the context of post-Saite and Persian rule, when I believe more serious adjustments to centralized rule occurred, the imposition of coinage was more a matter of contract between the king and the elites that exchanged rents and the acceptance of sovereignty for justice. That is not to say, however, that priests never found themselves in trouble with respect to Ptolemaic fiscal demands, as the Milon archive discussed below shows. But coinage is only part of a larger story of reform, which involved not only coercive pressure from above but also acceptance from below.

48 Cf. Eric Helleiner, 'Electronic Money: A Challenge to the Sovereign State?', Journal of International Affairs 51 (1998), 387-409.

49 Seaford, $M E G$.

50 Cf. the remarks of von Reden, 'Money' [n. 2], 165-6. 
An important aspect of this reordering of the countryside was the encapsulation of Egyptian law within the state. Codified law in Egypt, in the sense of a written set of rules, customs, and commentary on law, is documented directly only in Ptolemaic and Roman times, although there is a tradition that carries codified law back to the beginning of Egyptian history. Whether codified law existed in Egypt or not, the documentary evidence for codified law in the Ptolemaic period reflects Saite recentralization of the state and Persian codification recorded in the Demotic Chronicle, not sensu stricto a codification at all but in all likelihood merely an order to translate into Aramaic the existing legal traditions in Egypt. ${ }^{51}$ The most important Ptolemaic period document of Egyptian law is known as the Hermopolis legal code $(=P$. Mattha). There has been vigorous debate about the nature of this text, whether it is in fact a code similar to the Near Eastern codes, a kind of legal commentary, or a manual used by judges to decide cases. Be that as it may, the real question here is the origin of the text, and scribes to draw up instruments. Is it, as Pestman has argued, ${ }^{52}$ merely a Ptolemaic copy of a text generated in the eighth century вс by king Bocchoris, one of the 'lawgivers' of Diodorus, or is it the result of a broad codification of local traditions promoted by Ptolemaic rule? Others have suggested that the text is related to the tradition of Darius' collecting of Egyptian law. To be sure, the 'code' as we have it dates to the third century $\mathrm{BC}$, and most scholars accept a date in the reign of Ptolemy II based on paleography. The argument for an earlier date of composition is based on three incomplete dates in the papyrus that may refer back to the period between 645 and $582 \mathrm{BC}$, the mention of a pre-Persian form of marriage contract ${ }^{53}$ and, in a few places in the text, archaic orthography. The range of subjects covered in the Hermopolis code (and similar texts from the same period) is rather limited to formal rules of making contracts (sales, leases, and the like) and to procedure. The

51 D. B. Redford, 'The So-called "Codification" of Egyptian Law under Darius', in J. W. Watts (ed.), Persia and Torah. The Theory of Imperial Authorization of the Pentateuch (Atlanta, 2001), 135-59.

52 P. W. Pestman, 'L'Origine et l'extension d'un manuel de droit égyptien: quelques réflexions à propos du soi-disant code de Hermopolis', Journal of the Economic and Social History of the Orient 26 (1983), 14-21.

${ }^{53}$ J. H. Johnson, " "Annuity Contracts" and Marriage', in For his ka. Essays Offered in Memory of Klaus Baer, Studies in Ancient Oriental Civilization 55 (Chicago, 1994), 114. 
original editors of the text understood it as merely a part of a 'great code' yet to be discovered, making the incorrect assumption that a code must be comprehensive. ${ }^{54}$

Since its discovery in 1938-9 in a partially broken jar in the debris of a ruined building opposite the room of mummification'55 at Hermopolis, and its subsequent publication in 1975, the Hermopolis code has received much attention among scholars of demotic Egyptian. The milieu of such a text is no doubt a temple archive, and it probably originated in the House of Life-a temple scriptorium where important books on religion and traditional learning were copied.56 A Greek papyrus ( $P$. Oxy. 3285) from the second century AD shows some similarities to the Hermopolis text. In this Roman text, the existence of a copy may only suggest antiquarian interest by a priest rather than proof of the application of Egyptian law in the second century AD. It is certainly a Greek translation, probably going back to the early Ptolemaic period, of an Egyptian body of law.

It is tempting to associate the writing of this text with other efforts at early Ptolemaic state reorganization. Evidence is clear enough to show that the efforts of the early Ptolemaic kings to reorganize Egypt was systematic. The 'text' that provides us with the most important information about the nature of the Ptolemaic state survives only by way of references in other documents, where it is referred to simply as 'the legislation' (Greek to diagramma). ${ }^{57}$ Whether it occurred on one occasion, or over the course of several years, references to different sections of the 'legislation' suggest that the effort was a comprehensive one. Among other issues, it empowered courts to decide the law assigned to them, established rules for selecting judges, and promulgated maximum interest rates on loans. Bocchoris' reforms in the eighth century вс limited the maximum interest rate (Diod. Sic. 1. 79), but

54 On the wide range of definition of code, see J. Lindgren, 'Measuring the Value of Slaves and Free Persons in Ancient Law', in Chicago-Kent Law Review 71/1 (1995), 150-2.

55 G. Mattha and G. R. Hughes, The Demotic Legal Code of Hermopolis West, Bibliothèque d'Étude 45 (Cairo, 1975), p. xi.

56 A mathematical treatise is recorded on the verso of the Hermopolis text.

57 On this 'legislation' see H.-J. Wolff, 'Plurality of Laws in Ptolemaic Egypt', Revue Internationale des Droits de l'Antiquité 3 (1960), 191-223; J. Mélèze-Modrzejewski, 'The Septuagint as Nomos: How the Torah Became a "Civic Law" for the Jews of Egypt', in J. W. Cairns and O. F. Robinson (eds.), Critical Studies in Ancient Law, Comparative Law, and Legal History (Oxford, 2001), 190-3. 
a 100 per cent rate on a money loan is recorded in the fifth century вС. ${ }^{58}$ Interest rates for money loans under the early Ptolemies may be inferred to have been 30 per cent, reduced to 24 per cent per annum by the legislation of Ptolemy II, and later to maximum of 12 per cent in the early Roman period..$^{59}$

The process of Ptolemaicizing Egyptian institutions can, I think, be well understood in the light of Mancur Olson's 'stationary bandit' model. In such a model, the ruler binds himself by giving over rights and coercive power to constituent groups in the society in exchange for revenue extraction. The reforms of Ptolemy II may also have prompted the recording of Egyptian legal procedures that appear in Egyptian legal texts such as the Hermopolis legal code. The consolidation of legal traditions appears to have been a concerted effort to bring the constituent elements of Ptolemaic Egyptian society under the corporate structure of the state, while at the same time preserving the legal customs of the various populations in Egypt. Modrzejewski has recently suggested that we understand the writing of the Septuagint in the third century вс in the same light, i.e. as a confirmation of pre-existing Jewish law now in codified, Greek form. ${ }^{60}$ That the efforts of Ptolemy II reached villages in Upper Egypt as well as in the Fayyum is shown in the resolution of disputes within the context of Egyptian law. ${ }^{61}$

In his treatment of legal reforms, it is interesting to note that the Ptolemies are hardly given a mention by Diodorus other than to say that Egyptian institutions were changed by them:

The system, then, of law used throughout the land was the work, they say, of the men just named, and gained a renown that spread among other peoples everywhere; but in later times, they say, many institutions which were regarded as good were changed, after the Macedonians had conquered and destroyed once and for all the kingship of the native line.

(Diod. Sic. 1. 95. 6, Oldfather translation)

This is a rather harsh critique of Ptolemaic rule in Egypt, and was no doubt coloured by the realities of later Ptolemaic history, which, by

58 Pap. Hou 12 (= P. Loeb $48+49 A$ ), Hûw (Upper Egypt), 487 BC, republished and discussed by Vleeming, The Gooseherds of Hou [n. 11], 156-77.

59 On interest in Egyptian loans, see P. W. Pestman, 'Loans Bearing no Interest?', Journal of Juristic Papyrology 16-17 (1971), 7-29.

60 Mélèze-Modrzejewski, 'The Septuagint' [n. 57].

61 See the Asyut family archive discussed below. 
all accounts, was a very difficult time both politically and economically. Diodorus' time in Egypt, between the years 60 and 56 вс, were not happy years for Egypt. Documents both before and after these years are clear about the agricultural problems: communication lapses in the administration, flight from the land, crop failure culminating apparently in $48 \mathrm{BC}$, when Pliny (HN 5. 58) notes the lowest flood level known to him, no doubt part of a longer and unpleasant inter-annual trend. ${ }^{62}$

Ptolemaic institution building during the third century $\mathrm{BC}$ tells a rather different story than either Pliny's or Diodorus'. There were great successes, including the building of a new capital city at Alexandria, a new regional administrative centre at Ptolemais in southern Egypt, a massive land reclamation project in the Fayyum, an accommodation of Egyptian institutional structures at the same time as new Greek fiscal institutions, and the new administrative language (Greek), gradually replaced Egyptian economic and political structures. Because there are very few Greek documents dated to the reign of Ptolemy I, and the enormous amount of documentary material from the reign of Ptolemy II, it is usually assumed that it was the latter king who created the institutions of the Ptolemaic state. But an important first step, and an indication of a plan to govern Egypt, was taken by Ptolemy I in founding the southern Greek city of Ptolemais (modern el-Manshah) just above modern Sohag. The foundation of a Greek polis in this part of Egypt was a recognition that the Thebaid region (Aswan down to about Abydos) required strong administrative presence by the new regime. The Thebaid, centred on the temple of priesthood of the god Amun in Thebes in the first millennium $\mathrm{BC}$, was used to semi-independence from the political capital in the north. Another text of Ptolemy I, the Satrap Stela, shows that while he still functioned technically as a Persian governor (satrap) of Egypt, he functioned, in Egyptian eyes (the intended audience of the text) as a pious Egyptian pharaoh. The contours of royal ideology are already clearly established in this text.

With Ptolemy II's reign we have much more documentation in Greek and Egyptian, and it is assumed that this increase reflects not merely an accident of preservation but an increase in state activity, 322-3.

62 D. J. Thompson, 'Egypt, 146-31 BC', in CAH ix, 2nd edn. (Cambridge, 1994), 
and important changes in the taxation system including, importantly, the use of bronze coinage for certain tax payments. The well known Karnak Ostracon, for example, a demotic text usually dated to $258 \mathrm{BC}$, shows that a royal order to survey land reached the south of the country and the important temple of Amun at Thebes. ${ }^{63}$ Such an order emanated from the king himself, probably originally in the form of a prostagma, and was sent down the chain of the bureaucracy, and translated into demotic so that local priesthoods (or agents of the state) as well as farmers could be informed of what was expected by the Ptolemaic authorities who were responsible for generating a budget for the king. This suggests that the orders were intended to go through the temple bureaucracy, not through a separate bureaucracy, a good indication that the temple structure was utilized by the early Ptolemies for such administrative purposes. The order also clearly shows that information on tenure and water conditions flowed from the villages up to the capital and not the reverse. This is in any case the theory, and the text at hand is good evidence that the order penetrated deep into the Egyptian countryside to at least the powerful priesthood of the temple of Amun at Karnak.

Two important texts from the reigns of Ptolemy II and III show us the ideal of the bureaucracy, and the operation of the new fiscal system. ${ }^{64}$ The first text, P. Tebt. 703, dating to the early part of the reign of Ptolemy III Euergetes, is thought to contain a series of instructions from the chief financial official in Alexandria (dioikètēs) to an official in charge of nome finances (oikonomos). Its literary connections to earlier Egyptian instructions (of the Pharaoh establishing the proper code of conduct for officials and a sense of 'justice' between the state and its subjects) should be taken seriously, although the mention of difficult times suggests that the text was a specific attempt at restoring order after a period of civil unrest linked to a war and, perhaps, poor Nile flooding. ${ }^{65}$ The allusion to soldiers

63 E. Bresciani, 'Registrazione catastale e ideologia politica nell'Egitto tolemaico. A completamento di "la spedizione di Tolemeo II in Siria in un ostrakon demotico inedito da Karnak"', Egitto e vicino oriente 6 (1983), 15-31; S. M. Burstein, The Hellenistic Age from the Battle of Ipsos to the Death of Kleopatra VII (Cambridge, 1985), 122-3.

64 There are, of course, many other texts one could discuss in this context, not the least of which is Ps.-Aristotle's Oikonomika, clearly a type of blueprint for the royal economy. See Aperghis, The Seleukid Royal Economy [n. 5], 129.

65 Cf. the remarks of Crawford, 'The Good Official' [n. 44]. 
who have abandoned their duties reinforces this view. The long text covers many aspects of the royal economy from the maintenance of canals, to sowing, to the registration and care of cattle. The shipment of grain to the capital and the production of fruit trees are also given prominence. The text gives us a (static) picture of the bureaucracy and the central state's expectations of compliance and reporting.

The second text is known as the 'Revenue Laws Papyrus' (P. Rev.) and dates to the reign of Ptolemy II. The best-preserved section of the text deals with the production, the organization and the pricing of oil crops-sesame, castor, safflower among others (olive oil was not included in the regulations contained in $P$. Rev). On the basis of early translations of this text, it was thought that the entire process, from seed loans to survey of the fields, to tax collection, to the setting of the price of the raw material and its delivery to state factories, was centrally planned and controlled. The careful analysis by Bingen has shown, however, ${ }^{66}$ that the text is not, in fact, a systematic treatment of the collection of the royal revenues at all but, rather, a compendium of seven separate 'laws' (nomoi) issued by Ptolemy II Philadelphus governing a range of topics concerned with royal revenue, from tax farming to the oil crops and other key industries. The connection between the principles in the text and the rural economy is far more tenuous, and the ability of the state to plan the economy was far less than some earlier interpretations have suggested. Be that as it may, the demand for cash payments in bronze that P. Rev. suggests was important to the monetizing process.

In summation, Ptolemaic governance involved massive and systematic reform. Pharaonic ideology was combined with new signals, new fiscal institutions, and bargaining. In all of this coinage played a key role.

\section{MONEY AND THE PTOLEMAIC STATE}

Ptolemaic fiscal control of Egypt differed from earlier states in its demand for cash, but it took some time, presumably, for coinage and the idea of coinage to take hold in the chora. Yet Egyptians switched to 
the new system almost, so it seems, without a flinch, ${ }^{67}$ even if the circulation of coinage fell short of the nominal amount of the taxes in money demanded by the Ptolemaic fiscal system. ${ }^{68}$ The Ptolemaic state's demand for tax payments in coin was the principal engine of Ptolemaic monetization. The single most important tax, known in early Ptolemaic demotic sources as the yoke tax and subsequently as the salt tax, was assessed per capita. Every person, with notable exemptions for certain professions, was liable for this tax and the assessment of the tax meant that everyone was implicated in the economy in coin. The apomoira tax on vineyards raised money for temples as well as for the cult of Arsinoe II. ${ }^{69}$ A whole host of small taxes on professions and transactions was also collected in coin, either silver or bronze. ${ }^{70}$ Coinage may not have transformed the Egyptian countryside but it must have affected social relationships to some degree. The Ptolemaic taxation system utilized tax farmers and banks, both new fiscal institutions with which the rural population had to deal. The establishment of state banks was surely one of the key 'political strategies' of the early Ptolemaic state. ${ }^{71}$ Banks replaced the traditional economic function of temples as payment centres in areas such as the Thebaid, where tax receipts are documented by the end of the reign of Ptolemy I.

To be sure, the acceptance of coinage by Egyptians involved not only the Ptolemaic requirement that certain taxes be collected in coin, it also entailed the active willingness of the population to put faith in coins as a medium of exchange. ${ }^{72}$ The availability of coinage for tax payments and in private transactions, of course, depended on circulation, a technical problem that I cannot tackle here. ${ }^{73}$ The

67 Rowlandson, 'Money Use' [n. 37], 154.

68 Von Reden, Money [n. 26].

69 W. Clarysse and K. Vandorpe, 'The Ptolemaic Apomoira', in H. Melaerts (ed.), Le Culte du souverain dans l'Égypte ptolémaïque au IIIe siècle avant notre ère. Actes du colloque international, Bruxelles 10 mai 1995 (Leuven, 1998), 5-42.

70 See von Reden, Money [n. 26], for the details and the connections of bronze coin types to specific tax payments.

71 S. von Reden, 'The Politics of Monetization in Third-century BC Egypt', in A. Meadows and K. Shipton (eds.), Money and its Uses in the Ancient Greek World (Oxford, 2001), 66 n. 10.

72 Von Reden, 'The Politics' [n. 71].

73 See the excellent book on the history of small coinage by T. J. Sargent and F. R. Velde, The Big Problem of Small Change (Princeton, 2002). Cf. von Reden, Money [n. 26], 157. 
accounting system was monetized, although payments could be rendered in kind. Certain taxes were calculated in terms of coin, but often they, and wages, were paid in kind. ${ }^{74}$ The Ptolemaic monetization of the economy allowed for an easier conversion of crops into cash, and the interconvertibility of different crops for the payment of rent.

\section{EGYPTIAN PRACTICE}

The question of Egyptian practice, or the adaptation of coinage not only in taxation and also in small private transactions, is really a matter of assessing the degree to which the royal economy had penetrated into village and household economies. Samuel has stressed the traditional peasant mentality that clung to barter transactions, with little resort to market or 'public' transactions, and thus little use for coinage. ${ }^{75}$ Two levels were in place, even during the second century when bronze coins were used for small transactions. On the one hand the Ptolemaic coinage system was fully embedded in practice as a unit of account. On the other hand, Egyptian peasants were more engaged with social relationships in their village that used barter to establish relative values of goods to be exchanged when needed.

While the introduction of silver currency in Egypt by the Ptolemies was a century old by the time our second-century texts were written, the practice of using silver as the standard of exchange had by no means overwhelmed the long-established practice of reckoning in kind, and indeed, may even have receded to some extent after the first influx of Greeks into the countryside. ${ }^{76}$

Thus we may say that by the second century $\mathrm{BC}$, coinage had penetrated into most Egyptian households, but coins never became a kind of multipurpose money. It remained, rather, one means of payment, and it never fully replaced the natural economy. ${ }^{77}$ Furthermore, many (perhaps even most) of Egyptian sales from the Ptolemaic

\footnotetext{
74 P. Tebt. IV, p. 2; von Reden, 'The Politics' [n. 71], 70-1.

75 Samuel, 'The Money Economy' [n. 28].

76 Ibid. 202.

77 Cf. Bingen, Le Papyrus Revenue-Laws [n. 24], 212.
} 
period were probably not cash sales at all, but transfers of rights within families, and without, therefore, the need to draw up a written document. Many of the preserved written documents of sale were also not cash sales, but transfers of rights. ${ }^{78}$ In other words, even though the language of these contracts expresses the fact that a satisfactory 'price' had been paid by the 'purchaser,' the documents could be used for a wide variety of transfers of property rights, from proper sales that involved a transfer of cash to intra-family transfers that conveyed rights without payment. On the other side of the coin, as it were, are undocumented cash sales. These would include, for example, the sale of animals that are extremely scarce in the surviving Ptolemaic record for reasons I have laid out elsewhere. ${ }^{79}$ Egyptian marriage 'contracts' were also monetized, but they had been since the sixth century $\mathrm{BC}^{80}$ They express a cash sum that was payable to the woman upon divorce, and these marriage 'contracts' specified the value of the dowry in terms of silver and under the Ptolemies in Ptolemaic coinage. Demotic documents, therefore and perhaps surprisingly, are probably not good gauges of cash transactions in Egyptian villages and towns. On the other hand, the account papyri from the archive of Menches, a village scribe living at the end of the second century вс, show us the extensive use of cash exacted from and paid out to both private persons and officials in the course of the day-to-day operations of the land survey in a Fayyum village. ${ }^{81}$

Lending at interest appears to have been an institution late in coming in Egypt, known c.900 BC, and thus documented far earlier in the Near East. ${ }^{82}$ While this is strictly speaking true with respect to loan contracts, loans with interest are well known before this date

78 For one cash sale of land purchased at a public auction see P. Hausw. 16 (Edfu, 221-220 вс), discussed by Manning, 'The Auction of Pharaoh', in Gold of Praise. Studies in Honor of Edward F. Wente (Chicago, 1999), 277-84.

79 Manning, 'A Ptolemaic Agreement concerning a Donkey with an Unusual Warranty Clause. The Strange Case of P. dem. Princ. 1 (inv. 7524)', Enchoria 28 (2002-3), 46-61.

80 See E. Lüddeckens, Ägyptische Eheverträge, Ägyptologische Abhandlungen 1 (Wiesbaden, 1960), 289-321, on monetary values expressed in demotic marriage contracts.

81 A. Verhoogt, Regaling Officials in Ptolemaic Egypt, P. L. Bat. 32 (Leiden, 2005).

${ }_{82}$ M. van de Mieroop, 'The Invention of Interest', in W. N. Goetzmann and K. Geert Rouwenhorst (eds.), The Origins of Value. The Financial Innovations that Created Modern Capital Markets (Oxford, 2005), 17-30. 
from the New Kingdom village of Deir el-Medina. ${ }^{83}$ Loan contracts in demotic Egyptian are known from the early Persian period, but their paucity cannot be used to assess how common written loan contracts were at the time. In general loans in kind and in cash are among the most common contract types in demotic, and loans in kind are still the majority of preserved loan contracts of the Ptolemaic period. The majority of these are from the Thebaid and dated to the second century Вс but the distribution can in no way demonstrate secular trends in private lending, i.e. we cannot use the increase number of documented loans in the second century $\mathrm{BC}$ to suggest that private loans became more common in the later Ptolemaic period.

A group of demotic Egyptian papyri from Asyut, now in the British Museum, that does provide valuable insights into an Egyptian village in Upper Egypt preserves the oral transcript and supporting documentary evidence from a dispute between two half-brothers over the inheritance of two small plots of land that occurred in the early second century вс before judges in the temple of the local god. ${ }^{84}$ During the course of the oral proceedings, a complete list of the property of the priestly family is listed. All of this property is real property or shares of offices (priesthoods or scribes). Nothing in this reveals much about the new Ptolemaic economy in coin, and we can only guess if items such as revenue from local storehouses was generated in coin or in kind.

An important archive revealing much about lending in practice in the Egyptian countryside is the late-second-century $\mathrm{BC}$ archive of Dionysios son of Kephalas. ${ }^{85}$ Napthali Lewis has made a good case that Dionysios, who came from a Graeco-Egyptian military family, utilized his social connections within the military to lend money and grain. Far from being in a debt trap as was supposed,

83 e.g. P. Turin PR 9, mentioning a loan of grain with 50 per cent interest. On the history of lending in Egypt see B. Menu, 'Modalités et réglementation du prêt en Égypte à l'époque de la première domination perse', in Recherches sur l'histoire juridique, économique et sociale de l'ancienne Egypte, Bibliothèque d'études 122 (Cairo, 1998), ii. 385-99.

84 Manning, Land and Power [n. 4], 201-5.

85 E. Boswinkel and P. W. Pestman, Les Archives privées de Dionysios, fils de Kephalas, Papyrologica Lugduno-Batava 22 (Leiden, 1982); N. Lewis, Greeks in Ptolemaic Egypt. Case Studies in the Social History of the Hellenistic World (Oxford, 1986), 124-39. 
Dionysios was rather a 'master of sharp practice'. ${ }^{6}$ Dionysios owned and rented land in the area around the garrison town at Akoris, but it is his role as a lender that is the dominant feature of the papers that have come down to us. Two-thirds of the archive is devoted to his lending activities, and most of the loans were grain loans. In three cases, money loans were repayable in kind. Since the interest rate on loans in kind was traditionally set at 50 per cent of the loan, it seems there was incentive, intentional or not, to lend in kind rather than in cash, and convert the grain to cash when and if necessary. ${ }^{87}$ In both the case of the Asyut priests and Dionysios, access to real assets either through the temple or the new royal economy that privileged soldiers and state officials allowed persons to convert hard assets to liquid ones. ${ }^{88}$ It is obvious enough to say, and hardly surprising, that elites took advantage of economic opportunities as they presented themselves. Soldiers receiving salaries could be instruments of monetization, but as Bingen has shown, ${ }^{89}$ access to land, and in particular to the all-important wheat crop, was only an ad hoc and irregular feature of the royal economy, and it could not apply to the entire Greek immigrant population. In Bingen's view, the Greek mentalité of a monetary economy came straight up against an ancient agricultural regime that was only partly altered by the new institutions within the royal economy. The credit market still relied on personal contacts and trust between individuals within a family, or within the same status group, as the Dionysios archive shows.

The Ptolemies exacted a tax on property transfers. This transfer tax, known as the enkuklion in Greek documents, was in fact a continuation of an Egyptian tax on transfers that was in the control of local temples. The tax has been studied recently by Depauw in the publication of an early Ptolemaic demotic family archive from

${ }^{86}$ Lewis, Greeks [n. 85], 131.

87 For some cases of variable interest rates in loans in kind see K. Vandorpe, 'Interest in Ptolemaic Loans of Seed-Corn from the "House of Hathor" (Pathyris)', in Egyptian Religion, the Last Thousand Years. Studies Dedicated to the Memory of Jan Quaegebeur, Orientalia Lovaniensia Analecta 84-5 (Leuven, 1998), 1459-68.

${ }^{88}$ For loans in kind and in money for the military community at Pathyris in Upper Egypt see the important discussion by K. Vandorpe, The Bilingual Family Archive of Dryton, his Wife Apollonia and their Daughter Senmouthis, Collectanea Hellenistica 4 (Brussels, 2002), 105-217.

89 'Les Tensions structurelles' [n. 45]. 
Thebes. ${ }^{90}$ A complex document (much remains obscure) from Thebes dated to $291 \mathrm{BC}$ hints that taxes, in this case funerary taxes, were already being farmed in Thebes in the very early Ptolemaic period.91 If the current understanding of this text is correct, it provides important documentary evidence that either the Ptolemaic system was established quite early in the south, or, in my view more likely, the Ptolemaic system continued earlier economic institutions. The history of the transfer tax and related structures (banks, tax farmers, receipts) shows the mechanisms of Ptolemaic economic reform begun by Ptolemy II.

Much attention has been paid to the effect of the monetary economy on lower strata of society. Such is the case with the surety documents from the Fayyum in which small amounts of cash were paid to guarantee that work would be performed in certain industries such as beer making. ${ }^{92}$ Mummification was a cash business, and Egyptian temples also raised cash that is accounted for by the Ptolemaic official known as the praktor, in charge of temple finances, and the lesonis, a temple priest internally charged with fiduciary responsible of the temple to the state. If the third-century вс archive of Milon from Edfu is any guide, industrial activities of Egyptian temples (inter alia beer making and the manufacturing of linen and papyrus) in general were vital generators of cash, with officials such as the lesonis personally liable for shortfalls in expected income. ${ }^{93}$

\section{CONCLUSIONS}

The economic power of the state is historically the crucial element in the history of monetization and, as the Ptolemaic case shows, state

90 M. Depauw, A Companion to Demotic Studies, Papyrologica Bruxellensia 28 (Brussels, 2000).

91 The text is P. BM 10528, originally published in S. R. K. Glanville, A Theban Archive of the Reign of Ptolemy I Soter, Catalogue of Demotic Papyri in the British Museum 1 (London, 1939). It was republished and discussed by Depauw, Companion [n. 90], 70-4.

92 Bingen, 'Économie grecque' [n. 36].

93 On this archive see the fine overview of W. Clarysse, 'The Archive of the Praktor Milon', in K. Vandorpe and W. Clarysse (eds.), Edfu, an Egyptian Provincial Capital in the Ptolemaic Period (Brussels, 2003), 17-27. 
power to demand taxes in coin and payments into state banks were keys to the process. Yet the agricultural sector, overwhelmingly the largest, remained by and large a commodity economy. The creation of the Greek urban centres of Alexandria and Ptolemais, both minimally documented, must have played the key role in the increased monetization of the economy, as did the revitalization of the nome capitals within the Ptolemaic bureaucratic structure. Despite the new Greek fiscal institutions of the Ptolemies (banking, tax farming, public auctions), the very limited credit market outside friendship cliques created a barrier to the circulation of coin. The cash mentalité reflected in Ptolemaic accounting was thorough, but the private use of coinage appears to have been, like much else in Ptolemaic Egypt, a matter of degree as well as a matter of taste, and was highly variable in time and in space. Indeed Ptolemaic banks operated in both coin and in kind. ${ }^{94}$

Both Alan Samuel and Dominic Rathbone argued that the monetized economy did not affect the traditional rural economy. ${ }^{95}$ Samuel concluded, 'the fundamentally non-coinage orientation of the vast majority peasant activity in Egypt made coin-oriented segments of the administration of lesser importance in the aggregate of official activity, and significant rather to that very small body of Greek-speaking members of the population who actually had to do with commerce.'96 There may well have been, for the third century вс especially, a regional difference between the newly exploited area of the Fayyum, and the Thebaid, which was still dominated by ancient temple estates. The types of taxes also varied regionally. ${ }^{97}$ While we cannot be sure, the extensive documentary evidence for wine (not only in the Fayyum) and fruit tree production is, in my view, a good proxy measure of the reach of the Ptolemaic economy in coin into the countryside.

The history of coinage under the Ptolemies probably tracks rather closely the history of other Ptolemaic state institutions. ${ }^{98}$ Given the

94 R. Bogaert, 'Les Opérations en nature des banques en Égypte gréco-romaine', Ancient Society 19 (1998), 213-24.

95 Samuel, 'The Money Economy' [n. 28], Rathbone, 'The Ancient Economy' [n. 27].

96 A. E. Samuel, The Shifting Sands of History: Interpretations of Ptolemaic Egypt (Lanham, Md., 1989), 63.

97 On the impressive range of taxes see Préaux, L'Économie royale [n. 24], 591-5; Muhs, Tax Receipts [n. 12], for the Thebaid.

98 See von Reden, Money [n. 26], for the details of monetary integration and disintegration. 
elite and state-centred bias of the documents, this is perhaps no surprise. But the use of coinage highlights both the process of Ptolemaic state formation, a desire for homogeneity and predictability by the state, and the flip side of this, the variable adaptation of the new rules by the population. It does appear to be the case, as Samuel has argued, that on one hand elites (Greeks, Greek-speaking members of the bureaucracy, soldiers, and Egyptian priests) were more likely to buy into the Ptolemaic system and its institutions than were peasant farmers. But we must remember that this dichotomy was not one that distinguished Greeks from non-Greeks entirely. As we have seen in the Milon archive from third-century BC Edfu, Egyptian priests in the south were fully involved in the cash economy. Temple building projects there, beginning with the great Horus temple at Edfu in $237 \mathrm{BC}$, may have stimulated, in conjunction with the new tax and bank system, increased circulation of coin through the cycle of wage payments. Whatever the extent of private cash transactions, however, the Ptolemaicization of Egypt, including the acceptance of coins as a medium of exchange, and their use in general accounting of state revenue and payments, was both successful and thorough by the end of the third century BC. The supply of coins (we must always remember that there is no native silver mined in Egypt) lagged behind the use of coins as a unit of account and as a symbol of royal sovereignty. The persistence of the natural economy may also have allowed many to disguise private economic activity, but we will never know the extent of it. The codification of coinage by the Ptolemaic state was, nevertheless, an important institutional shift in the economic history of Egypt, and the Ptolemaic case provides one more example that coinage was a 'public symbol of political sovereignty. 99

99 B. G. Carruthers, 'The Sociology of Money and Credit,' in N. J. Smelser and R. Swedberg (eds.), The Handbook of Economic Sociology, 2nd edn. (Princeton, 2005), 355-78. 